\title{
O ONTEM E O HOJE DOS PAPÉIS DE GÊNERO EM NARRATIVAS MARAVILHOSAS
}

Luciane Tavares dos Santos é mestranda em Educação na Universidade do Estado do Pará (PPGED/UEPA); especialista em Literatura Infantil e Juvenil e graduada em Letras: Português-Literaturas pela Universidade Federal do Rio de Janeiro (UFRJ); bolsista CAPES. E-mail: tavaressluciane@gmail.com

\begin{abstract}
Resumo
O objetivo deste artigo é analisar os papéis de gênero nos contos clássicos e contemporâneos a fim de explicitar na construção de gênero das personagens femininas e masculinas protagonistas a forte influência de uma visão de mundo europeia, cristã e patriarcal que estaria na sua gênese e evolução.
\end{abstract}

\begin{abstract}
The aim of this paper is to analyze the gender roles in the classic marvelous and the contemporaneous tales, in order to reveal in the female and male main characters gender construction a strong influence of a EuropeanChristian-patriarchal world view, which would be in their genesis and evolution.
\end{abstract}

\section{1) Introdução}

Durante séculos, contos de caráter polimorfo e ligados ao pensamento mágico se consolidaram através da oralidade; ainda que esta tenha sido percebida e encarada por muitos, em geral, de forma marginalizada e diminuta - contribuindo para o sucesso de uma visão negativa e pejorativa que a pregava como sinônimo de iletramento -, estes contos se tornaram importantes meios de transmissão de cultura e ensinamentos para diferentes povos (ZUMTHOR, 1993).

Essa poesia não letrada, popular, folclórica, quando passa à escrita, conquista espaço privilegiado no meio literário, o que, de fato, permitiu sua preservação, mas, é também fato que, foi por intermédio da voz que resistira. Nossa infância literária se ancora na oralidade, que se configura como intrínseca à literatura, uma vez que é elemento constitutivo das narrativas folclóricas (PROPP, 2002); sendo assim, os antigos contadores de histórias, sem dúvida, têm papel mais que importante nesta trajetória.

A transmissão da memória e da experiência é atribuída aos contadores de histórias, que foram, segundo Santos (2012, p.1), “elemento fundamental para que as narrativas populares se [constituíssem] como herança de um patrimônio cultural extremamente rico que brota da oralidade, de fonte muitas vezes anônima, mas intrinsecamente ligada ao domínio do coletivo".

É difícil precisar a origem destes contos. No entanto, em especial no que tange à predileção pelo universo do encantamento e da magia, além das coincidências de episódios, motivos, etc., teria havido um fundo comum a todos eles. Coelho (1987, p.16) afirma que "a verdadeira origem das narrativas populares maravilhosas perde-se na poeira dos tempos" e que:

A partir do século XIX, quando se iniciam cientificamente os estudos de literatura folclórica e popular de cada nação, mil controvérsias são levantadas por filólogos, antropólogos, etnólogos, psicólogos e sociólogos, que tentavam detectar as fontes ou os textos-matrizes desse caudal de literatura maravilhosa (COELHO, 1987, p.16).

Constatou-se, séculos antes de Cristo, a existência de vestígios dessas narrativas de fontes orientais e célticas, que são as principais fontes formadoras do ciclo narrativo maravilhoso, ou pelo menos as mais remotas das quais se tem notícia. Para completar este amálgama literário, a partir da Idade Média, as narrativas célticas e orientais 
começam a ser integradas às europeias, no momento em que se tem a difusão de uma nova filosofia de vida sob o influxo do Cristianismo (COELHO, 1987).

Assim, a tendência observada é a de fusão entre o maravilhoso pagão, a cultura mágica e o espiritualismo cristão, limpando-se o erotismo presente nos contos de fontes orientais. Nas palavras de Coelho (1987):

\begin{abstract}
Mistura-se o sobrenatural diabólico (magos, duendes, particularmente o fabuloso Merlin), o maravilhoso das metamorfoses e a magia das fadas, em sua ambivalência de seres benéficos e maléficos. Dessa complexa mistura de elementos transparece o ideal de vida cristã, que tenta transformar a ordem sentimental em disciplina ética ou, ainda, confunde as emoções da arte e do amor com a ação prática do real (COELHO, 1987, p.59, grifos da autora).
\end{abstract}

O que se entende por maravilhoso aqui é "algo que evoca um conjunto de fenômenos extraordinários e incríveis que constituem as fontes essenciais das narrativas fantásticas. [...] É a experimentação total da realidade universal” (AMIM, 2006, p.88); para o homem medieval, por exemplo, serviu como modo de escapar a sua realidade medíocre ${ }^{1}$. Até hoje o universo do encantamento está diretamente ligado às necessidades do ser e do seu eu interior, talvez seja uma das razões que expliquem a permanência de elementos maravilhosos, sobretudo na literatura infantil (AMIM, 2006).

Amim (2006) ressalta que esses elementos teriam dupla funcionalidade: provocar um desequilíbrio na narrativa e combater a censura institucionalizada, pela Igreja - através da imposição do Cristianismo - ou embrenhada na psique dos autores. Sendo assim, o maravilhoso foi usado simbolicamente para destruir a nova ordem, por fuga ou recusa da realidade vigente, era um meio de transgredir padrões estabelecidos, normas ou leis; tem-se, portanto, o maravilhoso sendo usado contra as imperfeições do mundo cotidiano. Nas palavras de Martins (2010):

O clássico final feliz a que tem direito a maioria das personagens dessas histórias [...] constitui uma forma de apreensão de outra realidade. A invenção desse mundo ao contrário, ainda que somente no plano da fantasia, permitia aos camponeses tornaremse, também, eles, senhores - desposando princesas, fartando-se com iguarias reais e usufruindo do ócio e demais privilégios dos nobres. [...] Tudo isso nos faz acreditar que por trás da fantasia e do divertimento escapista dos contos populares existia um substrato de realismo social, uma denúncia das condições miseráveis da vida dos homens medievais e modernos (MARTINS, 2010. p.122; 124, grifos da autora).

Este desejo de fuga e apreensão de outra realidade também se revela no estímulo à competição entre as mulheres em busca de um lugar na hierarquia social. Por exemplo, as ascensões por intermédio de casamentos são comuns nos contos maravilhosos, de fadas. O clássico conto da Cinderela ou (A Gata Borralheira) ilustra

\footnotetext{
${ }^{1}$ A Idade Média foi marcada por grandes e distintos acontecimentos de ordem política, econômica, religiosa e artística e, também, por conflitos sociais, fome e miséria, sobretudo para a população camponesa. A Grande Peste marcou fortemente a população, principalmente pelo sentimento religioso, uma vez que ela foi encarada como um castigo divino devido aos não-cristãos. Essa situação instaurou um caos coletivo modificando os homens daquele período, bem como sua maneira de se comportar, de agir (AMIM, 2006).
} 
bem este cenário: um príncipe se apaixona por uma mulher comum, maltrapilha, suja, mantida como empregada pela madrasta e meias-irmãs que tentam sabotar sua "sorte", isto é, a possibilidade de um futuro diferente, ainda que apenas no plano da fantasia.

Além da ascensão social, o casamento cristão proporciona ascensão espiritual, ética e moral. Pode-se dizer que o Felizes para sempre é a representação de um amor eterno e indestrutível que se concretiza através do casamento, uma espécie de rito de passagem para o ideal de vida que estava sendo construído naquela época.

A influência religiosa fixou o ideário de premiação às virtudes e, castigo aos excessos, especialmente no caso das mulheres. Porém, já se divulgava, nas fontes primárias orientais e célticas, uma imagem dual das mulheres - anjo ou demônio - além de ser, também, o momento em que se registra o surgimento das primeiras mulheres sobrenaturais a darem origem à linhagem das fadas - boas ou más (COELHO, 1987).

Se a literatura é uma representação do real, ficam evidentes nas narrativas essas marcas trazidas da sociedade e de sua organização. Os fatores externos à ficção religiosos, culturais, políticos, econômicos - inevitavelmente estão diluídos nas narrativas, tornando o fazer literário, também, espaço de manifestação da moralidade maniqueísta.

Analisar-se-á os clássicos "Barba Azul", de Charles Perrault (2011) e "A Bela e a Fera", Jeanne-Marie Beaumont (1998), em contraposição aos mais recentes "A moça tecelã" e "A mulher ramada", de Marina Colasanti (1982), fazendo-se necessário, $a$ priori, apresentar uma contextualização histórica acerca da vigência de uma sociedade marcadamente patriarcal e o processo de cristianização, que deixaram suas marcas na passagem dessa literatura popular e, majoritariamente, oral para a escrita. Em um segundo momento, desvelar nas construções de gênero, das personagens femininas e masculinas, a presença das interpolações entre fontes céltico-orientais e europeias, dos vestígios dos ritos e mitos de sociedades primitivas que permaneceram como substrato poderoso junto aos elementos cristãos, que deram aos contos maravilhosos cara e corpo únicos.

\section{2) Fatores Extraliterários e suas Influências nas Narrativas Maravilhosas}

\section{1) Do Matricentrismo ao Patriarcado: Surgimento do Mito de Origem Cristão}

Todos os mitos de origem das grandes culturas tendem a sacralizar os seus principais valores, como afirma Muraro (2011, p.9), na introdução histórica do livro $O$ Martelo das Feiticeiras - Malleus Maleficarium. Este livro, escrito pelos inquisidores Heinrich Kramer e James Sprenger, no esplendor do Renascimento, traz em suas páginas o peso de três séculos de perseguições que atingiram intensamente às mulheres.

É necessário retornar ao mito da criação para entender como, onde e por que, deu-se a instauração de uma "caça às bruxas", na qual se usou de muita violência, para incutir nas massas os valores morais do Cristianismo. No entanto, Pierre Brunel (1998) alerta-nos para a necessidade de entender as diferenças entre o mito e o mito literário, além de ser preciso levar em conta "o mito propriamente dito"; atenta, também, para o fato de que isso não significa que literário seja somente o mito na literatura. Para Hilário Franco Jr. (1992): 
O mito é uma forma de conhecimento que equaciona as grandes questões espirituais e materiais da sociedade, sem pretender solucioná-las. É a exteriorização das grandes dúvidas, ansiedades, medos, expectativas e sonhos coletivos de cada comunidade. É uma mediação entre o abstrato e o concreto, expressada de acordo com a cultura da qual faz parte. É, então, uma manifestação do imaginário. Logo, está historicamente presente em todas as épocas, porém vivida de forma mais intensa e explícita nas sociedades arcaicas, nas quais a outra forma de conhecimento e de relação com o cosmo e com o social, a razão, ocupa espaço mais restrito, ainda que presente no próprio mito (FRANCO, 1992, p.11-12, grifo do autor).

Mircea Eliade afirma que o mito, por ser ligado ao conhecimento primitivo, conta uma história sagrada, haja vista revele o ser, o deus, cuja existência depende, pois, de uma crença, de fé, senão será apenas uma história (ELIADE apud BRUNEL, 1998, p. XVI). O "o mito narra um fato importante ocorrido no tempo primordial, no tempo fabuloso dos começos" (ELIADE apud BRUNEL, 1998, p. XVI), e tem como funções contar, explicar e revelar. Em suma, uma narrativa mítica é um relato de como uma realidade chegou à existência, como qualquer ser passou a existir.

A narrativa do Gênesis, "o mito por excelência” (BRUNEL, 1998, p. XVI) é a melhor ilustração para o entendimento desse conceito, entretanto há outros que explicam o surgimento do mundo, com origens bastante anteriores. Nas primitivas mitologias, há quatro tipos de mitos de criação, que curiosamente acompanham a cronologia da história da humanidade (MURARO, 2011, p.8).

Através desses mitos, é possível entender a trajetória da mulher até os dias atuais. Por exemplo, encaixa-se no primeiro tipo a mitologia grega, na qual a figura da Grande Mãe, a Mãe Terra (Geia), cria o universo sozinha. A Grande Mãe é amorosa e não impõe regras, pois "nos grupos matricêntricos, as formas de associação entre homens e mulheres não incluíam nem a transmissão do poder nem a da herança" (MURARO, 2011, p.6).

Há culturas que se enquadram em um segundo modelo, no qual os deuses feminino e masculino reinam em equilíbrio (o deus andrógino), caso da mitologia chinesa (yin e yang). Em outras, as deusas são destronadas e perdem seus lugares para os deuses masculinos. Por último, temos aquelas em que reina um único deus, masculino, que cria o mundo a partir de si mesmo - o mito persa é um exemplo, mas, acima de todos, está o mito cristão que é dominante em muitas culturas do mundo, principalmente as ocidentais (MURARO, 2011, p.8).

Dito isso, pode-se afirmar que, sim, "no princípio era a Mãe" (FRENCH, 1985 apud MURARO, 2011, p.8), já a sociedade patriarcal veio depois, levando quase à extinção a representatividade das divindades femininas, como destaca Muraro (2011):

A partir do segundo milênio a.C. [...], raramente se registram mitos em que a divindade primária seja mulher. Em muitos deles, estas são substituídas por um deus macho [...] centralizador, que dita regras de comportamento cuja transgressão é sempre punida. [...] E como todos os mitos fundantes das grandes culturas tendem a sacralizar os seus principais valores, [...] representa bem a transformação do matricentrismo em patriarcado. [...] A relação homem-mulher-natureza não é mais de integração e, sim, de dominação (MURARO, 2011, p.9-10). 
O Gênesis revela a condição de "não igualdade" entre homens e mulheres, pois, lê-se muito claramente que a mulher nasce do homem, depois que o mundo e ele próprio já estão plenamente criados pelo deus cristão - Javé. Imersos em um Paraíso, no qual nada falta, segundo o mito, a mulher cede aos encantos da serpente e leva o homem a pecar, ocasionando a fúria de Javé e a, consequente, expulsão do casal primordial (Adão e Eva) do Jardim do Éden. Se não tivessem desobedecido às ordens divinas, não teriam sido expulsos e o homem não sofreria com nenhum tipo de mazela, uma vez que ainda estariam protegidos sob a tutela de Deus, vivendo em harmonia e paz no Paraíso.

No período medieval, as tentativas de retorno a este local se concretizam em utopias, que servem não apenas de válvula de escape, mas como uma forma de salvação. Por exemplo, Franco (1992) privilegia quatro utopias tidas por ele como as mais expressivas naquele período, tais sejam, a utopia da abundância (Cocanha), a do milênio (a justiça), a do sexo (androginia ${ }^{2}$ ) e a utopia-matriz, o paraíso. Pode-se afirmar que a expulsão de Adão e Eva, de certa forma, deu origem às demais utopias, uma vez que todas elas se encerrem na mesma ideia: a nostalgia do Paraíso. Dentro desta busca, de uma realidade outra, o caráter religioso pode até parecer secundário, mas está mais do que explícito nessas sucessivas tentativas de retorno a essa terra que caracterizaria, sobretudo, a plenitude do bem e do amor de Deus para com os homens.

Voltar ao Paraíso restauraria a "ordem das coisas", do que fora perdido com o pecado. Esta busca incessante pelo Éden, seja como o lugar da harmonia, da fartura alimentar ou do aperfeiçoamento espiritual, moldou o imaginário coletivo do homem antigo de tal forma, que está sedimentada no imaginário do homem moderno; conscientemente ou não, ele busca uma vida harmônica, com fartura de bons sentimentos e valores; pois, ao fazer e buscar o bem, ele se tornará apto a uma pós-vida no Paraíso.

\section{2) Heranças do Medieval e Imposição do Cristianismo}

Da centralização do poder feudal, no fim do século XIII, à repressão sistemática do feminino, em finais do século XIV até meados do século XVIII, chega-se ao século XIX com uma civilização submetida a um estrito controle, completamente normatizada; e, ainda que fragmentados, os conceitos e padrões de pensamento/ comportamento da época são revelados não só nas personagens, mas em toda a matéria literária reunida/produzida no período.

\footnotetext{
${ }^{2}$ Segundo, Franco (1992), através da normatização do sexo e da sacralização do casamento, tentou-se eliminar o "profundo enraizamento" do sentimento andrógino de buscar a re-união dos opostos complementares através da satisfação dos desejos sexuais, no entanto, mesmo dentro da nova ordem, o casamento continua sendo uma forma de reunir os sexos, é a liberação para o ato sexual, mesmo que com suas restrições; e, no imaginário popular, o caminho para a edenização. Se na literatura o exemplo intransponível da eterna busca pela reintegração do sexo está em Tristão e Isolda, no culto à Maria, "versão cristã das arcaicas divindades femininas" (Ibid., p.92), tem-se a restauração mitológica do Deus primitivo, completo, bissexual, andrógino, que obviamente fora por muito tempo renegada pela Igreja, que "para afastar a reandroginização do Deus cristão não divinizou Maria naquele contexto de sociedade ainda misógina, apenas em meados do século XX a Igreja aceitou o dogma da Assunção" - o qual reconhece "uma quaternidade mais do que uma Trindade" (Ibid., p.93). 
Muraro (2011, p.14) afirma que "a religião católica e, mais tarde, a protestante contribuem de maneira decisiva para essa centralização do poder"; usando de muita violência, "através dos tribunais da Inquisição que varreram a Europa [...], torturando e assassinando em massa aqueles que eram julgados heréticos ou bruxos” (Ibid., p.14).

De acordo Amim (1993), a instauração do Cristianismo, em princípio, deu-se nas cidades, de forma superficial e restrita à aristocracia, enquanto que, no campo, a massa da população rural continuava ligada às antigas crenças pagãs. Só a partir de meados do século VIII, em que se destaca a força do Império de Carlos Magno (o escolhido e enviado por Deus), há uma assimilação maior dos valores cristãos - ao mesmo tempo em que ele fazia valer sua autoridade real.

A centralização do poder, a obediência absoluta à autoridade, a moral dogmática, a valorização do individualismo e suas verdades absolutas são a base do sistema capitalista, cujo embrião estava sendo implantado e sob o qual grande parte da população mundial contemporânea ainda está submetida; é ali, segundo Muraro (2011, p.14), que "começa a se construir o corpo dócil do futuro trabalhador que vai ser alienado do seu trabalho e não se rebelará". As regras morais estão arraigadas nos homens e nas mulheres até hoje, que se tornam eles mesmos patrulheiros e inquisidores, punindo transgressões, em especial a sexual:

\begin{abstract}
Neste contexto é que a Igreja regulamentou e sacramentalizou o matrimônio, tornando-o instrumento de controle eclesiástico sobre o setor laico da sociedade. Devido à misoginia eclesiástica, o casamento tornou-se ainda um reforço da autoridade masculina sobre a mulher. [...] A posição comum do coito para gregos e romanos, mulher por cima, homem por baixo, era considerada pelo cristianismo uma aberração. Para os teólogos, era posição adotada apenas no adultério e na fornicação, [...] imprópria à fecundação. O homem deveria ficar sobre a mulher - reproduzindo na posição sexual a posição social. (FRANCO, 1992, p.108)
\end{abstract}

O cenário é de desagregação. Valores "antigos" são constantemente postos em confronto com os "novos", seja pela vontade de romper com eles ou de mantê-los, e a literatura não passa ilesa em meio a esse turbilhão. As personagens carregam em si esses valores socioculturais que estavam sendo consolidados ali e, como questiona Coelho (2000), cabe analisar em toda a literatura herdada em que medida tais valores se transformaram em tipos de personagens, em linguagem literária, em temas, etc.

Ainda segundo Coelho (2000), o conhecimento da literatura produzida em uma determinada época, revela uma experiência humana que, mesmo não podendo ser definida com exatidão, coloca-nos em contato com "a singularidade de cada momento da longa marcha da humanidade em sua constante evolução" (Ibid., p.27), além disso, este conhecimento revela "os ideais, os valores ou desvalores sobre os quais cada sociedade se fundamentou [e se fundamenta...]" (Ibid., p.28, grifo da autora). Assim:

Torna-se fácil compreender por que a literatura foi usada, desde as origens, como instrumento de transmissão de valores. [...] Compreende-se que a linguagem poética (ou literária em geral) tivesse sido utilizada, desde os primórdios (através de rituais, por exemplo), para transmitir padrões de pensamento ou de conduta às diferentes comunidades. Uma vez que tais valores ou padrões (de natureza social, ética, política, 
artística, econômica, religiosa, etc.) são essencialmente abstratos, dificilmente poderiam ser compreendidos ou assimilados por mentes que vivem muito próximas da natureza sensorial, do concreto e, como tal, propensas a conhecerem as coisas através das emoções e da experiência concreta. Transmitidos em uma linguagem lógica racionalizante e abstrata (como a filosofia...), tais valores não as atingiriam a fundo. Daí a importância que a linguagem literária assumiu, para os homens, desde os primórdios da civilização. Ela é a linguagem da representação, linguagem imagística que, como nenhuma outra, tem o poder de concretizar o abstrato (e também o indizível), através de comparações, imagens, símbolos, alegorias, etc. (COELHO, 2000, p.43, grifos da autora).

Para além de hierarquias impostas ou existentes, a transmissão desses contos, ainda que subjugados como inferiores, crendices, folclore, preservam as características do homem e do seu povo e são, inclusive, símbolos da resistência à censura institucionalizada "pela nova visão de mundo gerada pelo espiritualismo cristão" (COELHO, 1987, p.15). Mais do que isso, há muitos detalhes nesses séculos, que devem ser pensados, como as influências e contribuições das mais diversas civilizações que tiveram seu povo e sua cultura assimilados - sobretudo as célticas, cujo substrato influenciou e moldou fortemente o homem medieval.

O surgimento das universidades (as quais foram talvez o maior legado da Idade Média) é outro fator relevante, uma vez que a literatura laica retratava toda a vida social, os costumes e o pensamento do período. Seria difícil resumir a diversidade literária dessa época, entretanto nela está exposto todo o cenário medieval, das migrações às Cruzadas, da influência da igreja à estrutura político-feudal (AMIM, 1993). Era extensa a produção com propósitos mais artísticos e satíricos que didáticos, dentre os quais se destacam a lírica trovadoresca e o romance cortês, pois havia uma necessidade de enobrecer e fazer ressurgir sentimentos que remontavam aos tempos heroicos dos grandes guerreiros (AMIM, 1993).

Isso é relevante para a análise do ideal masculino construído nas narrativas maravilhosas. O herói é o "modelo das qualidades consagradas pela sociedade, como padrões ideais a serem imitados" (COELHO, 2000, p.20), é cheio de virtudes, vence todos os obstáculos com inteligência, pois é persistente, tem esperança, fé. Até hoje, a criança, ao ler uma narrativa maravilhosa, identifica-se com o arquétipo do herói que escapa todo o acidental.

\section{3) Idealização e Exemplaridade nos Contos Maravilhosos: As personagens}

A Idade Média criou heróis e maravilhas destinadas a alimentar sonhos a longo termo, na maior parte das vezes através da sublimação das realidades sociais e materiais daquela época: catedrais, cavaleiros, amor, divertimentos e espetáculos, mulheres excepcionais que se situam entre Deus e satã (LE GOFF, 2009).

É fato, embora soe como óbvia constatação para muitos, que não há ação sem quem a execute. Na ação narrativa, não é diferente, cabe às personagens a função de, além de executar, viver a ação (COELHO, 2000). Fato é, também, que as narrativas não são estanques, imunes ao contexto de sua produção, sequer são imunes aos questionamentos de seus autores ou contadores. Logo, as personagens serão, além de 
meras executoras da ação, detentoras e divulgadoras - involuntárias ou intencionais das características socioculturais, da própria conduta humana, os comportamentos e os valores concernentes ao contexto no qual são (re)produzidas.

Importante atentar que todas as personas narrativas são mais típicas do que únicas (BETTELHEIM, 2007), mesmo com todas as interpolações, misturas, etc., todas compartilham características, de certa forma, herdadas de seus antecessores literários que, por sua vez, remetem a modelos primitivos do que é ser homem e mulher; mais do que isso, remetem às experiências "que parecem inatas, representando uma herança do espírito humano" (JUNG, s.d. apud MENDES, 2000, p.35), os chamados arquétipos, que são na concepção de Jung:

Uma forma de pensamento ou de comportamento, um símbolo das experiências humanas básicas, que são as mesmas para qualquer indivíduo, em qualquer época e qualquer lugar. Sendo resultado de uma experiência que foi repetida durante muitas e muitas gerações. [...] Os arquétipos criam mitos, religiões e filosofias que influenciam e caracterizam nações e épocas inteiras (JUNG, s.d. apud MENDES, 2000, p.35).

Tais arquétipos são facilmente identificados em várias concepções míticas primitivas, tão antigas quanto o próprio homem. A repetição de eventos, como o nascimento, a morte e o casamento, bem como as figuras narrativas, exemplificam bem e comprovam a existência destes "resíduos arcaicos" (FREUD, s.d. apud MENDES, 2000, p.35) que veem sendo transmitidos século após século, já que conservam-se no imaginário coletivo:

É só pensarmos nas cosmogonias primitivas, e esse fenômeno torna-se claro: todas elas explicam a gênese do mundo e da condição humana através de mitos. Assim, também, todas as formas alegóricas, através das quais a Bíblia registra para o mundo cristão a gênese do mundo, encontram correspondência no mundo antigo greco-romano em uma rica e complexa mitologia (COELHO, 2000, p.169-170, grifo da autora).

Dessa mistura complexa, destacam-se as já mencionadas fadas. Seres imaginários complexos, de comprovada importância para os contos maravilhosos, que embora a origem não se possa precisar nesse emaranhado mitológico - surgem como personagens nas novelas de cavalaria do ciclo Arturiano (COELHO, 2000) e conectamse com a imagem do feminino no seu sentido mais primitivo. Retomando o filósofo O. Spengler, citado por Nelly Coelho (2000), a mulher representaria "uma força primordial, necessária e, ao mesmo tempo temida" (Ibid., p.177) no universo:

O feminino está mais próximo ao elemento cósmico, mais fundamente aderido à terra, mais imediatamente incorporado aos grandes ciclos da natureza. $\mathrm{O}$ masculino é mais livre, mais animal, mais movediço, e no perceber e compreender, é mais desperto e mais tenso. $\mathrm{O}$ homem vive o destino e concebe a causalidade, a lógica do produzido segundo causa e efeito. Porém, a mulher é destino, é tempo, é a lógica orgânica do próprio futuro. [...] Sempre que o homem pretendeu tornar palpável o destino, recebeu a impressão de algo feminino: as moiras, as parcas... O Deus máximo não é o próprio destino, mas um deus que representa ou domina tal destino; como o homem à mulher. $\mathrm{A}$ mulher nas épocas primitivas é também a vidente, não porque conheça o futuro, mas 
porque é futuro. O sacerdote somente interpreta. A mulher é o oráculo, o próprio tempo fala nela (SPENGLER, 1952 apud COELHO, 2000, p.176-177, grifos da autora).

A aproximação da figura feminina descrita por Spengler com a figura da fada é explícita, especialmente ao afirmar que "a mulher é destino, é tempo, é a lógica orgânica do próprio futuro". Ora, o destino se encera na palavra "fada" - fatum - que significa "destino" em Latim, além disso, a principal missão delas nos contos é "prever" e "prover" o futuro de alguém, assim como as moiras, as parcas, etc. (COELHO, 2000). Outro ponto a destacar é a natureza dual tanto das fadas quanto da mulher. Se o feminino representa uma força necessária e temida no universo, também as fadas, as quais que revelam ora a face luminosa, ora a sombria. Uma vez que elas são o destino, podem provê-lo ou cortá-lo, como se cortassem de fato o fio da vida, frustrando a realização do ser.

Esta dualidade é inerente não só a elas, mas aos seres humanos, que não são essencialmente bons ou ruins, mas os dois. No entanto, com o fortalecimento do patriarcado, reforçado pela Igreja e pelo Cristianismo, essa natureza intrínseca passa a ser sufocada, culminando na dominação de um sexo pelo outro (FRANCO, 1992). No lugar da integração harmoniosa entre os sexos e a natureza, passa a vigorar uma tentativa de se estabelecer modelos ideais (no sentido de serem, não melhores, mas superiores) de homem e mulher, tornando qualquer um monstruoso aos próprios olhos (BETTELHEIM, 2007). Mendes (2000), que estudou o significado das funções femininas nos contos de Perrault, afirma que:

\begin{abstract}
O estudo das origens dos contos de Perrault poderá comprovar também que neles estão todos os elementos já identificados e analisados nos mitos e contos de fadas de um modo geral, desde os arquétipos do inconsciente coletivo até os valores sociais e morais, sejam eles dos aristocratas, dos burgueses ou dos camponeses. [...] falam dos prêmios e castigos que a sociedade patriarcal determinou para as mulheres, e também do poder feminino da antiga sociedade matriarcal. Mas, acima de tudo, eles mostram os modelos de comportamento que a ideologia familista da burguesia escolheu como ideais para as crianças e as mulheres: a submissão, o conformismo e a fragilidade. (MENDES, 2000, p.88-89)
\end{abstract}

Diante disso, afirmar que as narrativas são representações microscópicas do real, não se constitui em um exagero, pois as necessidades reais do homem e do seu tempo são verificadas nelas e nem o processo de patriarcalização nem a repressão à prática pagã foram suficientes para sufocar ou apagar por completo arquétipos primitivos, do homem e suas experiências, compartilhados inconscientemente desde a Antiguidade.

Também não é de se espantar que o espaço das narrativas se torne uma forma de vencer, ainda que no plano imaginário, as questões mais íntimas dos seres e os infortúnios da vida cotidiana (FRANCO, 1992), uma vez que "nem mesmo a morte impede um justo final feliz [...], a justiça natural e infalível constitui um dos grandes atrativos dos contos de fadas [...], seus monstros e vilões nos fazem estremecer, sofremos com seus heróis e heroínas e nos alegramos quando tudo acaba bem" (PHILIP, 1998, p.13). 


\title{
3) Masculino e Feminino nos Contos Maravilhosos Clássicos
}

De acordo com Coelho (2000), personagens questionadoras do mundo não são comuns em narrativas antigas; nestas são corriqueiras as personagens-tipo e as personagens-caráter, centradas na função social e no comportamento ou padrões morais, respectivamente. Como exemplificado pela autora, as personagens-tipo são facilmente identificadas pelo leitor, por nunca mudarem suas ações e reações, são os reis, as rainhas, bruxas, fadas, bem como aquelas que desempenham funções de trabalho, como o lavrador, o servo e o pescador. Já as personagens-caráter são mais complexas por representarem "os pensamentos, impulsos ou ações que as movem na trama narrativa revelam sempre aspectos do caráter, da estrutura ética ou afetiva que as caracteriza" (Ibid., p.75). Pondera a autora, no entanto, que:

\begin{abstract}
Obviamente não há uma linha demarcatória que seja absoluta ou rígida entre essas duas categorias. Uma personagem permanece tipo quando sua atuação na história se limita à superfície das relações humanas. Pode passar a caráter quando tal atuação se torna mais complexa e se aprofunda no questionamento dos valores. Um eloquente exemplo dessa personagem é o famoso D. Quixote. Aparentemente um tipo caricatural dos "cavaleiros andantes" das novelas de cavalaria medievais, no decorrer da trama novelesca se transforma em um dos mais ricos personagens-caráter da literatura universal devido à genialidade com que Cervantes o criou (COELHO, 2000, p.75-76).
\end{abstract}

Analisando os contos "Barba Azul", de Charles Perrault e a "Bela e a Fera", Jeanne-Marie Beaumont, percebe-se, exatamente, personas narrativas que não permanecem tipo. Bela é o modelo exemplar e ideal do feminino, por ser muito boa e obediente ao pai, possuidora de uma conduta impecável, totalmente o oposto da esposa de Barba Azul, a qual pode ser caracterizada como o exemplo da mulher indesejável (no que tange ao caráter); pois, em vez de acatar as ordens de seu marido, acaba por desobedecê-lo - gerando fúria e necessidade de punição. Ambas propagam padrões de comportamento e valores que partem do masculino para o feminino, cabendo a elas a submissão a tais regras.

A construção dessas personagens se dá sob uma lógica dualística excessivamente maniqueísta - ou são excessiva e essencialmente boas ou são más, diabólicas e cruéis - evidenciando modelos superiores e inferiores e de forma que fiquem explícitos as punições e os castigos devidos àquelas que se desviam por quaisquer motivos do padrão que lhes cabe. Mendes (2000) pontua que:

Os prêmios e castigos para as boas e as más ações são a base da moral ingênua, que caracteriza as narrativas de origem popular. Por essa razão estão presentes em todos os contos de Perrault, mas em três deles - Chapeuzinho Vermelho, Barba Azul, As fadas as mulheres recebem prêmios e castigos especiais, que mostram o modo como o feminino é manipulado pela sociedade patriarcal (MENDES, 2000, p.94).

São contos aparentemente inofensivos, para muitos apenas assustadores, que instruem acerca do respeito e da obediência absoluta devida à autoridade, a moral dogmática diante dos quais a aceitação deve suplantar o questionamento. 


\title{
3.1) Análise do conto "Barba Azul"
}

No conto "Barba Azul", de Charles Perrault (2011), a curiosidade feminina é punida macabramente. O quarto que esconde as esposas mortas pelo sádico Barba Azul não deixa dúvidas de que ele teria sido um perfeito serial killer hollywoodiano nos dias de hoje. Para Marina Warner (1999), autora de Da Fera à Loira, Barba Azul representa dois arquétipos primitivos, o Deus pai, patriarcal, e o demônio, ratificando tais associações ao discorrer sobre os significados escondidos na barba:

\begin{abstract}
A barba separava os homens dos meninos nos Jogos Olímpicos; na visão de santo Agostinho, "a barba indica homens fortes; indica homens jovens; vigorosos, ativos e rápidos". A barba era também a marca do bode, e, dado o caráter libidinoso e diabólico desse animal, seu parentesco com os sátiros e outras personificações clássicas da luxúria, como o deus Pã, e com o próprio Demônio (que efetivamente usa barba azul no vitral do século XIV que se vê na igreja de Fairford, no Gloucestershire), a barba progressivamente veio a definir o gênero masculino de modo priápico. [...] Concedia- se às barbas um valor simbólico muito maior no Islã do que no mundo cristão. [...] Completamente fora de moda na corte do Rei Sol, a barba do vilão de Perrault sinalizava um estranho, um libertino, um rufião. A palavra mesmo em francês - barbe dá a impressão de estar relacionada à barbare, embora a etimologia continue fantasiosa (WARNER, 1999, p.275-276).
\end{abstract}

A autora também discorre sobre os significados escondidos na cor azul:

[...] a cor da profundeza ambígua, ao mesmo tempo do céu e do abismo, codifica o caráter terrível de Barba Azul, de sua casa e de seus atos, tão certamente quanto os anjos envergam branco e dourado. [...] Azul é a cor do lado sombrio, o matiz do maravilhoso e do inexplicável, do desejo, do conhecimento, da fotocópia azul, [...] da melancolia, do raro e do inesperado (WARNER, 1999, p.276).

É ao mesmo tempo a personificação da tentação (como a serpente que incitou Eva ao pecado) e o Deus pai (que pune pela desobediência). As semelhanças deste conto com o mito de criação cristão são muitas, tornando inevitável a analogia: "da época em que foi escrito o Gênesis até os nossos dias, isto é, de alguns milênios para cá, essa narrativa básica da nossa cultura patriarcal tem servido ininterruptamente para manter a mulher em seu devido lugar" (MURARO, 2011, p.12).

Assim como vivia o casal primordial, em harmonia e rodeado de tudo o que precisava, também Barba Azul de nada padecia, era homem de muitas propriedades e riquezas, como descrito no início do conto: "Era uma vez um homem muito rico que tinha muitas propriedades, todas nobres palácios, na cidade e no campo. Tudo nos castelos era belo e suntuoso, suas baixelas de ouro e de prata, as cadeiras estofadas com as finas tapeçarias e as carruagens adornadas de ouro" (PERRAULT, 2011, p.15). Entretanto, tanto em um, quanto n'outro havia um interdito: no conto, um quarto e, no mito de criação, um fruto; ambos em pleno alcance da fruição.

É interessante notar que, por mais assustador e monstruoso que seja um marido homicida, o foco narrativo está na curiosidade da esposa, na sua desobediência. Não fica claro, nem se pode afirmar, se o conto consiste em denúncia ou endosso e, embora o 
final deste conto tenha sido de alguma forma feliz, fica evidente a advertência às mulheres, ao seu comportamento reprovável, e aos homens que se deixam dominar pela cólera. A salvação da esposa, ao final, é, sobretudo, uma maneira de deixar viva com ela tal advertência. Mais do que isso, é fruto da condescendência divina, em respostas às suas preces: "dá-me apenas algum tempo para que eu possa fazer minhas preces", diz a esposa quando está prestes a ser punida. A esperteza e a astúcia vencem a força bruta e a prepotência neste conto, mas, ora, só Deus poderia salvá-la em momento tão perturbador, e ele a salva.

Outro ponto interessante desse conto é sua aproximação àqueles do ciclo do noivo animal, como A Bela e a Fera. Logo no começo da narrativa de Perrault (2011), diz-se que "apesar da riqueza, ele tinha uma tristeza: sua barba era azul" (Ibid., p.15) e que "a barba o fazia parecer tão feio e assustador que as moças fugiam quando se deparavam com ele" (Ibid., p.15). Após a inicial recusa da moça, e tendo ela o conhecido melhor, passou a achá-lo "um bom sujeito" (Ibid., p.16), apesar de sua aparência, tal qual Bela.

Bettelheim (2007) aponta que a diferença entre os dois está no amor, ou falta dele, pois "aquilo que ocorre em 'Barba Azul' não tem nada a ver com o amor" (Ibid., p.406), mas, sim, com a vontade dele de satisfazer sua vontade, seus desejos sexuais mais sombrios, "mantidos ocultos atrás da porta permanentemente fechada" (Ibid., p.406). Para Bettelheim (2007, p.403): "é um conto a respeito da tentação sexual [...]. É um conto a respeito dos aspectos destrutivos do sexo".

A ideologia que grassava na época, difundida por intermédio da Igreja, tinha suas bases na centralização do poder, logo, enquadrar homens e mulheres dentro de regras e padrões de comportamento era extremamente necessário para controlá-los. A repressão da mulher e do prazer se tornam práticas comuns, haja vista a transgressão sexual ser entendida como transgressão da fé e, em um "mundo teocrático", esta é vista como "transgressão política" (MURARO, 2011, p.15). As teses centrais do Malleus Maleficarum, segundo Muraro (2011), explicam com clareza o motivo de serem as mulheres as mais perseguidas:

1) O demônio, com a permissão de Deus, procura fazer o máximo de mal aos homens a fim de apropriar-se do maior número possível de almas. 2) E este mal é feito prioritariamente através de corpo, único 'lugar' onde o demônio pode entrar, pois 'o espírito [do homem] é governado por Deus, a vontade por um anjo e o corpo pelas estrelas'. E porque as estrelas são inferiores aos espíritos e o demônio é um espírito superior, só lhe resta o corpo para dominar. 3) E este domínio lhe vem através do controle e da manipulação dos atos sexuais. Pela sexualidade que o primeiro homem pecou e, portanto, a sexualidade é o ponto mais vulnerável de todos os homens. 4) E como as mulheres estão essencialmente ligadas à sexualidade, elas se tornam as agentes por excelência do demônio (as feiticeiras). $\mathrm{E}$ as mulheres têm mais conivência com o demônio 'porque Eva nasceu de uma costela torta de Adão, portanto nenhuma mulher pode ser reta' (MURARO, 2011, p.15).

Há oscilação entre uma ética maniqueísta e uma relativista - sendo que no fim, o Bem sempre é recompensado e o Mal, castigado. Bettelheim (2007) não acredita que as 
personagens deste conto evoluíram, não aprenderam com a lição, etc., no entanto, do ponto de vista ideológico, o conto cumpre seu papel - uma vez advertida a mulher e eliminado o demônio, ela transcende através das suas boas ações. Tendo herdado todos os bens de Barba Azul, ela emprega parte de sua fortuna para casar a irmã com um jovem fidalgo, e a outra parte em benefício dos dois irmãos (PERRAULT, 2011), além de usar uma parte em prol dela mesma, casando-se com um nobre homem.

\section{2) Análise do conto "A Bela e a Fera"}

Mais um conto em que cabe ao feminino um olhar que vá além das aparências. Em “A Bela e a Fera", de Jeanne-Marie Beaumont (1998), a metamorfose do homem encantado em animal só pode ser desfeita por uma mulher, possuidora de características distintas - "virgem, bela e boa" - que, a priori, é uma salvadora, mas na realidade é apenas uma ferramenta para o homem saciar os mais animalescos desejos. Segundo Warner (1999):

Ela tem de aprender a sabedoria (humana) superior de enxergar além das aparências externas, compreender que a monstruosidade reside no olhar do espectador, enquanto que a fera revela-se irresistivelmente bela e o mais elevado bem. A história da Bela e da Fera é um conto de fadas clássico de transformação (WARNER, 1999, p.310).

Logo no início do conto, as boas características da heroína são ressaltadas, a começar pelo seu nome: ela é "bondosa, meiga e tão bonita que todos a chamavam de Bela” (BEAUMONT, 1998, p.36). Ao contrário das irmãs, Bela tem caráter impecável, além de ser a mais obediente ao pai, isto é, ela é exemplo da conduta feminina apropriada. Já a Fera é descrita sempre com palavras que não fogem ao campo semântico do monstruoso e do horrendo; além disso, importante frisar que Fera é uma criatura dual - meio homem, meio animal - fato que retoma o ideário primitivo acerca do ser humano.

Sabe-se que o pai era um rico mercador que perdeu tudo, menos uma casa no campo para onde se muda com seus três filhos e suas três filhas. Nada é dito sobre a mãe de Bela, cujas atenções se voltam inteiramente para a figura paterna. Após um ano, este recupera sua mercadoria perdida e, antes de sair para buscá-la, pergunta às filhas o que elas gostariam que lhes desse quando voltasse (BEAUMONT, 1998). Enquanto as irmãs pediam joias caras, vestidos, a bela menina pediu apenas uma rosa, dada a insistência do pai em perguntar se ela não queria nada. No entendimento de Bettelheim (2007):

Os eventos fatídicos são desencadeados pelo fato de um pai ter roubado uma rosa para levar para sua filha predileta, a caçula. O fato simboliza tanto seu amor por ela quanto uma antecipação de sua perda da virgindade, uma vez que a flor arrancada particularmente a rosa arrancada - é um símbolo para a perda da virgindade. Isso pode parecer tanto ao pai quanto à filha como se ela tivesse de passar por uma experiência 'animalesca', mas a história mostra que suas angústias são infundadas; o que se temia 
viesse a ser uma experiência animalesca, revela-se uma experiência de profunda humanidade e amor (BETTELHEIM, 2007, p.409).

A simbologia sexual novamente se faz presente em um conto maravilhoso. Porém, diferente de Barba Azul, neste a experiência é menos perturbadora. Fera é, tal qual Barba Azul, a figura animalesca que busca saciar seus desejos através da bela menina - "Então você tem uma filha..." (BEAUMONT, 1998, p.38) - que, mesmo aterrorizada, entende que o pai errou por culpa dela, se ela não tivesse pedido uma rosa, isso não teria acontecido (BEAUMONT, 1998). Ora, mais uma vez a mulher é a causadora do pecado, mesmo a mais resignada das mulheres, a mais bondosa e meiga, é capaz de conduzir o homem ao erro. Portanto, ela se sacrifica para salvar o pai, indo ao encontro da criatura, esperando reparar o mal cometido: "Vou corrigir meu erro e pedir a Fera que nos perdoe!" (BEAUMONT. p.38). A princípio, Bela acredita que será devorada, mas passa a enxergar bondade no animal através do convívio.

Por fim, é a coragem de Bela e sua capacidade de amar a Fera independente de sua forma física, quebram o encantamento (BEAUMONT, 1998). Isto pode ser entendido como a resistência desta ao casamento forçado com um completo estranho, arranjado pelo pai, daí a necessidade de se exaltar a possibilidade de se construir uma relação amorosa:

O conto de fadas da Bela e da Fera supunha, de modo geral, um público composto por mulheres que contavam inteiramente com o fato de serem entregues por seus pais a homens que podiam muito bem parecer-lhes monstros. A revolução social que instituiu o casamento romântico e camaradesco como a norma, alterou de modo irreversível a recepção de tais romances e, ironicamente, transformou o exame que certas mulheres faziam de sua sorte matrimonial em propaganda materialista para se fazer um bom casamento (WARNER, 1999, p.313).

Assim, fortifica-se o patriarcado e a ideologia cristã que mantêm estrito controle sobre o casamento, a sexualidade e o amor. Em nome do amor, Bela se sacrifica ora pelo pai, ora por Fera. Faz-se a vontade tirana do masculino neste conto, pois, ainda que imersa em um casamento amoroso e feliz (construído a partir da intimidade, da convivência e da troca), apenas o feminino necessita ser: punido por ter induzido o homem ao erro; testado na sua capacidade de enfrentar o desconhecido; desafiado a provar sua boa essência e superior sabedoria para enxergar além das aparências da horrenda criatura. Dessa forma, a heroína cumpre seu desígnio, superando todos os obstáculos impostos. A problemática existencial é resolvida através da concretização do amor à Fera (a estrutura patriarcal se mantém, ao sair da tutela do pai, passa a ser responsabilidade do marido).

Esse ideal romântico que permeia o conto de "Bela e a Fera", já tão antigo, é análogo ao famoso "Eros e Psiquê", mais antigo ainda. Assim como Bela, "Psiquê é condenada a se casar com um monstro e acaba sendo amada por uma criatura misteriosa (PHILIP, 1998, p.41)", no entanto, ao tentar descobrir a identidade do amante (Eros), ela o perde. Para Warner (1999): 
A falta de confiança e desobediência de Psiquê lhe custou a adorável presença e o amor de Eros. [...] Depois de castigada por sua desobediência, Psiquê tem que provar seu amor através de muitas aventuras e provações; grávida de Eros, ela é submetida a repetidos testes de lealdade até que, finalmente, essa bela volta a se unir com sua Fera e adapta seu amado, o deus do amor, à condição humana do casamento (WARNER, 1999, p.309).

Psiquê teve que cumprir uma série de testes para ser novamente merecedora do amor de Eros, como Bela teve que provar ser merecedora do amor de Fera. A condição errante inerente ao feminino está tão diluída nas narrativas que o invólucro da busca pelo amor verdadeiro perfeitamente a mascara. Ao feminino cabe adequar-se, redimirse, entregar-se, tanto que ainda hoje o amor é o constituinte da identidade do feminino e se encontra sob estrito controle da família, da religião e da sociedade; sem falar nas aspirações e nas idealizações mais íntimas impostas pelas próprias mulheres.

Um exemplo contemporâneo, análogo a este conto, é o filme Shrek, grande sucesso entre crianças e adultos. No filme, um ogro (dos mais verdes e feios) e uma princesa se apaixonam perdidamente, provocando rebuliços na terra encantada onde vivem. Contra a benção de seu pai, e os olhares tortuosos e repletos de preconceito das pessoas do seu reino, a princesa Fiona abandona tudo para casar-se com o ogro Shrek, inclusive sua beleza, assumindo uma forma ogra. Apesar de aclamado com um filme diferente, que prega o não preconceito, a aceitação do outro pela sua essência, na verdade, Shrek não é nada inovador no que tange ao feminino - ainda que se assuma sátira dos contos de fadas. Por mais independente que o filme tente retratá-la, ainda há um ideário que deposita no feminino a submissão, a aceitação, o "fazer tudo pelo amor verdadeiro", mesmo que ele esteja em um ogro feio e ranzinza.

\section{4) Masculino e Feminino nos Contos Maravilhosos de Hoje}

Diferente dos contos maravilhosos tradicionais, nos quais a natureza dual dos seres humanos é comumente reprimida, na contemporaneidade, é típica a construção complexa da personagem nas suas mais variadas nuances. Se questionar o mundo não era comum às personagens tradicionais, na nova ficção tal questionamento é corriqueiro. Coelho (2000) classifica como personagens-individualidade as que colocam "em questão a antiga interpretação do ser humano, visto de maneira maniqueísta e dogmática, como um bloco inteiriço de qualidades ou de defeitos (Ibid., p.76)". Sendo assim:

A personagem tradicional (de aspecto físico, gestos, ações e sentimentos integrados em uma estrutura coerente e lógica) é substituída pela personagem-individualidade, que se revela ao leitor através das complexidades, perplexidades, impulsos e ambiguidades de seu mundo interior. [...] Representando o ser humano em diferentes graus de seu mistério interior, a personagem-individualidade é ambígua, exige de seu leitor maturidade de espírito e capacidade de reflexão (COELHO, 2000, p.75).

A autora cita o estranho menininho d'O Pequeno Príncipe, personagem de Saint-Exupéry e a espevitada menina Emília, do brasileiro Monteiro Lobato, como expoentes famosos de personagens-individualidade (COELHO, 2000, p.75), mas aqui 
analisar-se-á as personagens feminina e masculina de Marina Colasanti, autora que vai à contramão da manutenção de modelos ideais, superiores; de papéis tão engessados no certo e no errado, no bem e no mal. Colasanti aborda em muitos dos seus contos o amor romântico como constituinte da identidade feminina, entretanto de forma diferente daquela apresentada nos contos maravilhosos tradicionais:

\begin{abstract}
Embora a origem dos contos de fada date da era pré-cristã, a ideologia por eles transmitida serviu perfeitamente aos ideais pedagógicos da sociedade cristã-burguesa, que, no século XVII, já se preparava para fazer prevalecer o seu ideário político, econômico e social. Tanto o mito de Psiquê quanto a história de Cinderela mostram que a mulher terrena [...] deveria ser linda, ingênua e obediente. Esses predicados torná-laiam merecedora dos bons serviços dos deuses e das fadas. O prêmio final é o casamento, pelo qual ela se realiza como mulher e serve de exemplo às gerações vindouras, preservando os valores morais determinados pela sociedade. O poder só pode ser divino ou masculino (MENDES, 2000, p.143).
\end{abstract}

Colasanti considera "a união entre um homem e uma mulher como uma aliança, representando uma identidade partilhada (BESNOSIK, 2008, p.6)" em vez de concebêla como um prêmio definidor e fundamental à existência e realização da mulher. Nos seus contos, recupera noções primitivas acerca do que é ser mulher, nas quais o feminino determina o seu próprio destino, justamente por ser o destino.

\title{
4.1) Análise do conto "A Moça Tecelã"
}

"No princípio era a mãe" (FRENCH, 1985 apud MURARO, 2011, p.8). Neste conto de Marina Colasanti (1982), a ideia de um mundo criado pelas mãos de uma mulher é central. Tal qual nas sociedades matricêntricas, a mulher, nesta narrativa, é a grande mãe criadora de tudo e todos. Colasanti também recupera a simbologia do tear, único instrumento auxiliar da moça na sua função de criar, dar vidas as coisas; ela tecia, literal e temporalmente, desde o nascer do sol até o cair da noite:

Acordava ainda no escuro, como se ouvisse o sol chegando atrás das beiradas da noite. E logo se sentava ao tear. Linha clara, para começar o dia. Delicado traço cor da luz, que ela ia passando entre os fios estendidos, enquanto lá fora a claridade da manhã desenhava o horizonte. Depois lãs mais vivas, quentes lãs iam tecendo hora a hora, um longo tapete que nunca acabava [...] E à noite, depois de lançar seu fio da escuridão, dormia tranquila (COLASANTI, 1982, p.12-14).

O mesmo fio que tecer as manhãs também as destece, em um jogo duplo de vida e morte depositado nas mãos da tecelã; mais do que isso, nas mãos do feminino - que fia $o$ fatum - que é a primeira forma de divindade, antecedendo às representações masculinas. Importante frisar que, neste conto, não há menções a aparência física ou a beleza da personagem feminina, predicados antes muito importantes para defini-las (como na maioria dos contos maravilhosos da tradição), não estão nem implícitos nas entrelinhas, ficando a cargo da imaginação elaborá-los. Tudo que se sabe dela é que é uma moça, que é tecelã, que cumpre sua função com prazer todos os dias. $\mathrm{O}$ foco narrativo está, majoritariamente, no ato de tecer ou destecer, o dia, a noite, o tempo e, 
também, o próprio marido, não que isso signifique dominá-lo como forma de subverter a organização patriarcal ainda vigente.

A criação do marido é muito mais nostalgia do sentimento andrógino, uma vontade de re-unir os sexos primordiais através da integração, do que outra coisa: "mas tecendo e destecendo, ela própria trouxe o tempo em que se sentiu sozinha, e pela primeira vez pensou como seria bom ter um marido ao lado" (COLASANTI, 1982, p.15). Assim, idealização do marido é transposta para o tear e logo ele ganha vida. Aqui o casamento não é um prêmio resultante das boas ações da moça, nem imposto pela vontade do pai, é fruto da vontade e aspirações do feminino, o que não é garantia de um casamento bem-sucedido:

Com capricho, de quem tenta uma coisa nunca conhecida, começou a entremear no tapete as lãs e as cores que lhe dariam companhia. E aos poucos seu desejo foi aparecendo, chapéu emplumado, rosto barbudo, corpo aprumado, sapato engraxado. Estava justamente terminando de entremear o último fio da ponta dos sapatos, quando bateram à porta. Nem precisou abrir. O moço meteu a mão na maçaneta, tirou o chapéu de pluma, e foi entrando na sua vida (COLASANTI, 1982, p.14).

O modo como o moço entra porta adentro parece prenunciar o desenrolar da ação. Tomando conta de tudo e dando ordens à mulher, ele não hesita em requisitá-la ("ordenar" e "exigir", são alguns dos verbos usados por ele) para ter seus caprichos atendidos - palácios, carruagens, prataria, etc. - e assim, o que por um tempo foi prazer e felicidade, logo deu lugar a tristeza: "Sem descanso tecia a mulher os caprichos do marido, enchendo o palácio de luxos, os cofres de moedas, as salas de criado" (COLASANTI, 1982, p.15).

Por trás dos desmandos do marido, se há alguma mensagem sendo transmitida, com certeza, é a de que a ambição desmedida e a insaciabilidade humana causam desequilíbrios sem conta. Portanto, assim como trouxe o tempo em que se sentiu sozinha, ela trouxe, também, tempos mais felizes, uma vez que a presença do moço só lhe causou uma tristeza maior do que a vontade de tê-lo como companheiro (COLASANTI, 1982, p.15). Assim, ao se dar conta que é dona da própria história e que destecê-lo seria uma possibilidade de recriá-la, voltou a sorrir.

Este conto traz novas acepções sobre a relação homem-mulher, sobre o amor e o casamento, bem diferentes daquelas encontradas nos contos de "Barba Azul" e "A Bela e a Fera". A protagonista não apenas nomeia a narrativa, ela é a narrativa, afinal, tecer é dar vida ao emaranhado de fios que é a própria história, assim como Penélope, na mitologia grega, criou o próprio tempo, tecendo de dia e destecendo à noite, na esperança do retorno de seu amado. A imagem da mulher que o século XXI herdou é pautada na dominação e na subserviência, entretanto, no texto de Colasanti, submeter-se a um marido, e aos seus desmandos, deixa de ser a única opção e se ela é a causadora do bem e do mal desde o início dos tempos, também pode desfazê-los, controlá-los.

\section{2) Análise do conto "A Mulher Ramada"}

Em "A Mulher Ramada”, de Marina Colasanti (1982), digladiam-se os valores 
do passado e as necessidades do presente em direcionar ao feminino um olhar diferente daquele da maioria dos contos maravilhosos da tradição, nos quais é comum a descrição da personagem feminina vir acompanhada de suas virtudes, qualidades exigidas, que se não lhe são inerentes, devem ser cultivadas a fim de evitar a punição.

Neste conto, um jardineiro, imerso no tédio dos seus dias solitários, dá a vida a uma companheira, a mulher ramada, feita de ramos e amada - Rosamulher: "Trazidas num saco duas belas mudas, o homem escolheu o lugar, ajoelhou-se, cavou cuidadoso a primeira cova, mediu um palmo, cavou a segunda, e com gestos sábios de amor enterrou as raízes" (COLASANTI, 1982, p.27).

Segundo a narrativa, ele passa meses cuidando dela, regando e podando seus ramos para que fiquem exatamente como ele idealiza. Ao leitor desatento a conclusão de que esta é mais uma narrativa na qual o homem toma para si a posse da mulher, à sua vontade e gosto, porém cabe notar que, apesar das inúmeras tentativas do jardineiro em mantê-la em um molde, "os espigões teimosos" escapavam "à harmonia exigida" (COLASANTI, 1982, p.27).

Não quer o jardineiro qualquer beleza, mas aquela da sua idealização, por outro lado, tão pouco quer Rosamulher ter sua natureza emoldurada; e, mesmo não tendo uma voz na narrativa, fala pelo seu corpo, por cada galho que desponta do seu interior, tornando-a disforme aos olhos do homem, que incessantemente a podava, adiando seu florescer: "Enquanto todos os arbustos se enfeitavam de flores, nem uma só gota de vermelho brilhava no corpo da roseira. Nua, obedecia ao esforço de seu jardineiro que, temendo viesse a floração romper tanta beleza, cortava rente todos os botões" (COLASANTI, 1982, p.28).

Cabe lembrar que a voz feminina é considerada perigosa aos homens cristãos e condenada como imprópria - "Eva pecou pela palavra" (WARNER, 1999, p.57) - tão perigosa quanto à linguagem que emana do seu corpo. Por isso a necessidade de controlar suas artimanhas, seus ramos, bem como evitar a sua floração plena - aqui no conto, impedindo Rosamulher de ganhar vida através da maturação, pelo viés de sua própria vontade, o masculino continua a controlar o feminino, deixando-o mudo e sexualmente normatizado:

Para a tradição cristã, as virtudes do silêncio, obediência e discrição eram especialmente, se não essencialmente, femininas, mas essa visão se propagou bem além do círculo dos devotos. A Mulher Silenciosa era um ideal aceito. O clichê a respeito do sexo feminino, 'O silêncio vale ouro', foi prenunciado nas páginas de Aristóteles: 'o silêncio é a glória da mulher', escreve ele na Política, acrescentando, 'mas não é igualmente uma glória masculina' (WARNER, 1999, p.55-56, grifos da autora).

Com tudo, a mulher ramada não permite que sua história seja podada por outrem e como a moça tecelã entremeia os fios de lã no tear, ela entremeia seus ramos deixando livre sua natureza. Ao aceitar que Rosamulher é (e será) do jeito que quer ser, ambos inauguram um novo começo, tirando da escuridão uma concepção de amor, de união, há muito esquecida, a da integração dos sexos para além da possessão e do autoritarismo marital. Ora, um novo feminino requer um masculino outro. 
Portanto, o rompimento com o ciclo de resignação neste conto de Colasanti (1982) é condizente a nova condição do feminino, que mesmo sob forte pressão idealizante, tenta a todo custo impor seu discurso, contar sua história através da sua própria voz. O final feliz aqui não é o "viveram felizes para sempre”, não é o casamento enquanto premiação, mas, sobretudo, é o estabelecimento de um amor com suas bases em um respeito mútuo, de igual para igual, não sendo necessária a metamorfose dela ou dele para tal; no fim, o abraço dos amantes sela o novo começo.

\section{Conclusão}

Ao passar para a escrita, as narrativas orais sofrem inúmeras interpolações da ordem vigente. Textos de fontes céltico-orientais são incorporados aos de fontes europeias em meio ao apogeu da sociedade patriarcal, da centralização do poder e da instauração de um ideário cristão. Percebe-se que permanecem os arquétipos primitivos (pré-cristãos) frutos de experiências passadas da raça humana, que são constantemente ressignificados em toda a sua trajetória. No entanto, em meio à já sinalizada centralização de poder nas mãos do masculino, saltam aos olhos a repressão sistemática de tudo que foge aos padrões e valores ideais estabelecidos pelos dominantes por intermédio da Igreja, como por exemplo, a repressão da sexualidade como forma de manter estrito controle sobre o corpo delas, as mulheres, entendido como porta de entrada para o demônio.

Ao analisar contos maravilhosos de grande repercussão, verifica-se que são, sobretudo, as personagens femininas as divulgadoras da obediência absoluta, da moralidade, da prudência, da docilidade frente aos desígnios do marido, etc. Nota-se que, ainda hoje, tais padrões persistem; no entanto, não reinam soberanos.

Ressalta-se que, na atualidade, tais contos são leitura destinada, em especial, às crianças e, por isso, há que se refletir criticamente, questionar a quem servirá o maniqueísmo presente nestes contos, os ideais impostos ao feminino e ao masculino. As crianças, apesar de subjugadas pelos adultos como inferiores, são plenamente capazes de internalizar os padrões de gênero feminino e masculino que circulam em nossa sociedade e que estas narrativas legitimam e perpetuam.

Em um mundo essência patriarcal, de fato, tende-se a diminuir a representatividade da mulher, mas estas cada vez mais buscam pela justiça que lhes cabe, pelo direito de terem direitos iguais aos dos homens. É notável uma forte tendência à quebra destes modelos de homem e mulher, são muitas as produções que nadam contra a correnteza numa tentativa justa de "ressignificá-los". Assim, o feminino e o masculino ganham nova roupagem, moderna, de fato, como os novos tempos devem ser; Se antes ao feminino cabia o silêncio, nos contos maravilhosos atuais, percebe-se cada vez mais este silêncio - forçado - sendo rompido.

\section{Referências}

AMIM, M. Mabinogion: o maravilhoso e o utópico na construção da identidade galesa. 2006. 231 f. Tese (Doutorado em Ciência da Literatura: Literatura Comparada) Faculdade de Letras, UFRJ, Rio de Janeiro, 2006. 
Religião e poder na Busca do Graal: o desvelamento da história no jogo intertextual. 1993. Dissertação (Mestrado) - Faculdade de Letras, UFRJ, Rio de Janeiro, 1993.

BEAUMONT, Jeanne-Marie. "A Bela e a Fera”. In: PHILIP, Neil. Volta ao mundo em 52 histórias. São Paulo: Companhia das Letrinhas, 1998.

BESNOSIK, R. L. O amor e a feminilidade nos contos de Marina Colasanti. In: Congresso Internacional de Leitura e Literatura Infantil e Juvenil (CILLIJ), 2008. Anais... Porto Alegre: PUCRS, 2009. Disponível em < http://migre.me/gizdd $>$. Acesso em: set. 2013.

BETTELHEIM, Bruno. A psicanálise dos contos de fadas. Tradução de Arlene Caetano. 21 $1^{\mathrm{a}}$ ed. São Paulo: Paz e Terra, 2007.

BRUNEL, Pierre (dir.). Dicionário de mitos literários. Tradução Carlos Sussekind et al. $2^{\mathrm{a}}$ ed. Rio de Janeiro: José Olympio, 1998. p. XV-XX.

COELHO, Nelly Novaes. Literatura Infantil: teoria, análise, didática. $1^{\text {a }}$ ed. São Paulo: Moderna, 2000.

O Conto de fadas (Série Princípios). São Paulo: Ática, 1987.

COLASANTI, Marina. Doze reis e a moça no labirinto do vento. Rio de Janeiro: Editora Nórdica, 1982. p. 12-17; 26-31.

FRANCO, Hilário. As Utopias Medievais. 1ª ed. São Paulo: Brasiliense, 1992.

LE GOFF, Jacques. Heróis e maravilhas da Idade Média. Tradução Stephania Matousek. Petrópolis (RJ): Vozes, 2009. p. 9-31.

MARTINS, G. O Maravilhoso Cotidiano de João e Maria. In: Literatura infantil e juvenil na prática docente / GENS, Rosa; WERNECK, Leonor; MARTINS, Georgina (Orgs.). Rio de Janeiro: Ao Livro Técnico, 2010.

MENDES, M. B. T. Em busca dos contos perdidos: o significado das funções femininas nos contos de Perrault. UNESP (SP): Imprensa Oficial do Estado de São Paulo, 2000.

MURARO, Rose Marie. Breve introdução histórica. In: O martelo das feiticeiras / Heinrich Kramer e James Sprenger. 22 ${ }^{\mathrm{a}}$ ed. Rio de Janeiro: Rosa dos Tempos, 2011.

PERRAULT, Charles. Barba Azul. In: Contos de fadas em suas versões originais. Curitiba: Alquimia Editorial, 2011. v. 1, p. 15-23.

PROPP, Vladímir. As raízes históricas do conto maravilhoso. Coleção biblioteca universal. $2^{\text {a }}$ ed. São Paulo: Martins Fontes, 2002.

SANTOS, L.A. O Conto de fadas: da oralidade à literatura infantil. In: Encontro Nacional de Literatura Infanto-Juvenil e Ensino (ENLIJE), IV, 2012, UFCG. Anais... 
Editora Realize: Campina Grande, 2012. Disponível em: http://migre.me/fhJrE. Acesso em: jul. 2013.

WARNER, Marina. Da fera à loira: sobre contos de fadas e seus narradores. São Paulo: Companhia das Letras, 1999. p. 274-293; 307-334.

ZUMTHOR, Paul. A letra e a voz: a "literatura" medieval. São Paulo: Companhia das Letras, 1993. 